\title{
JUURNAL.RU
}

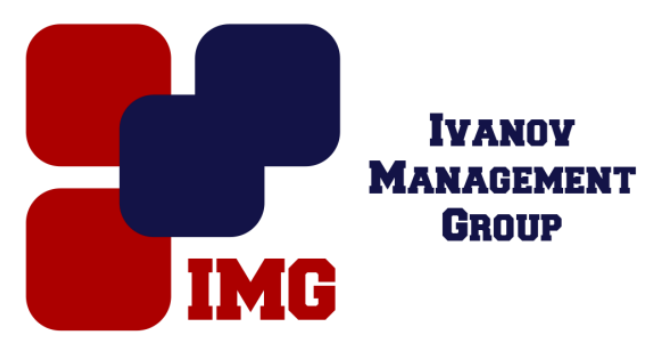

Меладзе Р.Д.

Тульский государственный университет Тула, Россия

doi: 10.18411/1j-31-03-2017-2-11

idsp 000001:1j-31-03-2017-2-11

\section{Уровень знаний о репродуктивном здоровье среди студенток медицинского института}

Знания в области репродуктивного здоровья являются важным аспектом в жизни любой женщины, достигшей периода половой зрелости. От состояния репродуктивного здоровья и установок правильного ведения половой жизни женщины зависит ее способность к зачатию и вынашиванию будущего ребенка. Для осуществления достаточного контроля и своевременного ухода за своей половой системой необходимы базовые знания и правильные репродуктивные установки у женщин в период вступления в половую жизнь.

Целью настоящего исследования являлось выявление базовой грамотности студенток медицинского института в области репродуктивного здоровья на примере длительности собственного менструального цикла.

Объектом исследования послужили 378 студенток Тульского медицинского института, обучающиеся по специальности «Лечебное дело» с первого по пятый курс. Данные по вопросам репродуктивного здоровья были изучены с помощью анкетирования [1-3]. В анкетировании среди прочих вопросов были заданы в частности вопросы о собственной длительности менструального цикла и длительности менструального кровотечения.

Возраст студенток, участвующих в анкетировании, варьировал от 17 до 29 лет в зависимости от курса обучения и составил в среднем 20,04 $\pm 0,09$ лет. В ходе исследования обнаружено, что 20 студенток (5,3\%) указали заведомо ошибочную длительность их менструального цикла в пределах от 2 до 7 дней включительно. Распределение ошибочных ответов по курсам обучения (I курс 12 студенток (3,2\%), II курс - 3 студентки $(0,8 \%)$, III курс - 2 студентки $(0,5 \%)$, 
IV курс - 1 студентка (0,25\%), V курс - 2 студентки (0,5\%)) свидетельствует о более высоком уровне ошибок среди студенток младших курсов и выравнивании ошибок до минимума к пятому курсу.

Так же были допущены ошибки в вопросе о длительности менструального цикла, но в дальнейшем исправлены у 64 студенток (16,9\%). Максимальный уровень исправлений наблюдался у студенток первого-второго курса (I курс - 26 студенток (6,8\%), II курс - 14 студенток (3,7\%), III курс - 9 студенток $(2,4 \%)$, IV курс - 7 студенток $(1,9 \%)$, V курс - 8 студенток $(2,1 \%))$.

Установленный более низкий уровень как ошибочных, так и исправленных ответов в области репродуктивного здоровья среди студенток старших курсов медицинского института закономерно отражает устойчивые знания о функционировании женской половой системы вследствие последовательного изучения профильных предметов «Репродуктивное здоровье» и «Акушерство и гинекология» на втором и четвертом-пятом курсе обучения.

Таким образом, уровень знаний студенток медицинского института в области репродуктивного здоровья на примере длительности собственного менструального цикла можно расценить как достаточный, но требующий акцентирования вопросов репродукции на младших курсах.

\section{Литература}

1. Агарков Н.М., Павлов О.Г. Медико-социальные проблемы беременных в юном возрасте. Проблемы социальной гигиены, здравоохранения и истории медицины. 1997. № 4. C. 18-21.

2. Павлов О.Г. Сочетанная соматическая патология родителей и репродуктивная функция их дочерей. Вестник новых медицинских технологий. 2011. Т. 18. № 3. С. 248-250.

3. Павлов О.Г. Прикладные вопросы ситуационного управления в социальномедицинской сфере. Старый Оскол: ТНТ, 2009. 276 с.Шумилин А.И., Шпиняк С.П., Пичхидзе С.Я. К вопросу повышения износостойкости вкладыша коленного эндопротеза. Саратов: СГУ, 2016. - 3c. 